\title{
Asymptomatic Multiple Laryngeal Cysts in Multinodular Goitre Patient
}

\section{Multinodüler Guatr Hastasında Asemptomatik Mültipl Larenks Kistleri}

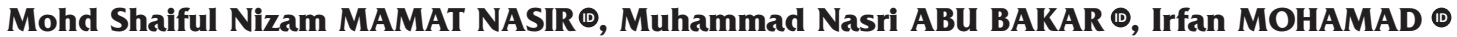

Ethics Committee Aproval: Not Applicable.

Confillict of Interest: The authors declare that they have no conflict of interest.

Funding: None.

Informed Concent: Informed consent was taken.
Cite as: Mamat Nasir MSN, Abu Bakar MN, Mohamad I. Asymptomatic Multiple Laryngeal Cysts in Multinodular Goitre Patient. Medeniyet Med J. 2019;34:229-32.

\begin{abstract}
Multiple laryngeal cyst in adult are rare entity. Laryngeal cysts are usually benign lesions. They rarely cause symptoms unless they progressively increase in dimension or enlarge in due of course of time. Here we described a case of asymptomatic patient with multiple laryngeal cyst in elderly which was successfully treated with endoscopic surgery without complication.

Keywords: Larynx; vallecula; cyst

öz

Yetişkinde mültipl larenks kisti nadirdir. Larenks kistleri genellikle iyi huylu lezyonlardır. Boyutları giderek artmadıkça veya zamanla genișlemedikçe nadiren semptomlara neden olurlar. Burada endoskopik cerrahiyle komplikasyonsuz başarlyla tedavi edilmiş multipl larenks kistleri olan bir olguyu tanımlıyoruz.
\end{abstract}

Anahtar kelimeler: Larenks, vallekula, kist

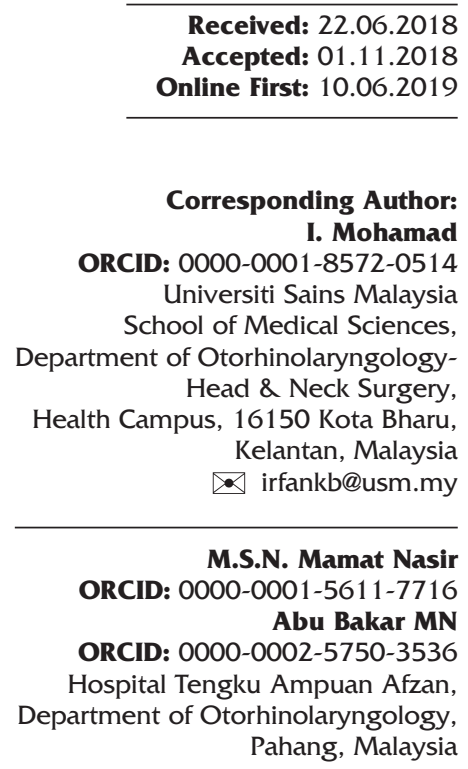

Received: 22.06 .2018

Accepted: 01.11.2018

Online First: 10.06.2019

Corresponding Author:

I. Mohamad

ORCID: 0000-0001-8572-0514

Universiti Sains Malaysia

School of Medical Sciences, Department of Otorhinolaryngology-

Head \& Neck Surgery,

Health Campus, 16150 Kota Bharu,

Kelantan, Malaysia

irfankb@usm.my

M.S.N. Mamat Nasir ORCID: 0000-0001-5611-7716

Abu Bakar MN

ORCID: 0000-0002-5750-3536

Hospital Tengku Ampuan Afzan, Department of Otorhinolaryngology, Pahang, Malaysia

\section{INTRODUCTION}

Laryngeal cysts are usually benign and rare entities. Lingual surface of the epiglottis is their most common location, especially when the lingual tonsillar crypt or duct of mucous gland become dilated and obstructed ${ }^{1}$. Depending on position and size of the cyst, the presentation varies. Bigger cysts may cause hoarseness or dysphagia.
Usually cysts in the larynx are asymptomatic in adult and discovered during induction of anesthesia or routine laryngoscopy ${ }^{2}$. Laryngeal cysts usually do not require treatment and do not warrant surgical intervention, but in pediatric age group, especially in infants, this lesion may be associated with feeding difficulties and airway obstruction ${ }^{3}$. Symptomatic laryngeal cyst usually treated surgically either by excision or marsupialisation. 


\section{CASE SUMMARY}

A 68-year-old man presented with progressively increasing left neck swelling for one-year. There was no history of dysphagia, hoarseness, noisy

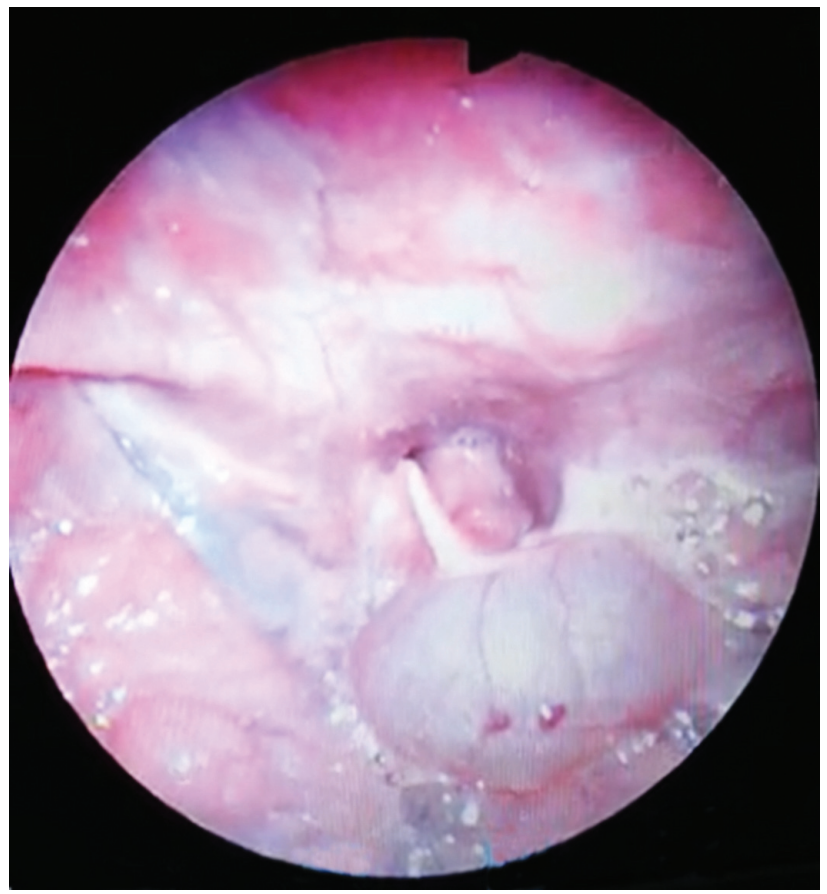

Flgure 1. A FNPLS revealed a large globular mass with smooth surface at the vallecula region.

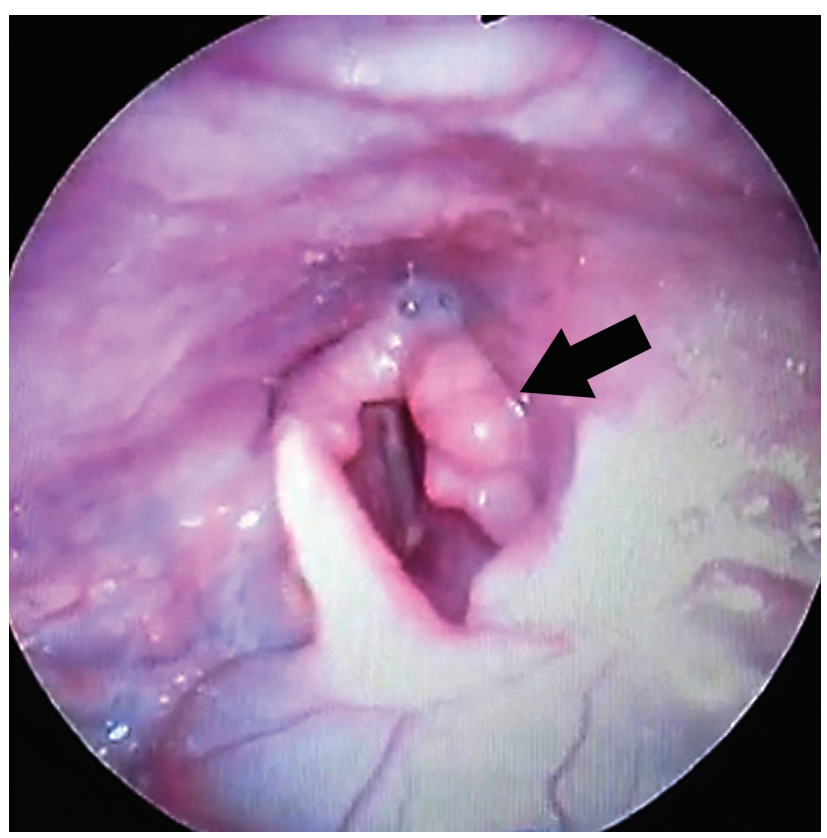

Figure 2. A FNPLS revealed a small globular with smooth surface mass at the left arythenoid (Arrow). breathing or neck trauma. He also denied history of fever or swelling elsewhere. Physical examination revealed a huge left neck swelling measuring $12 \mathrm{~cm} \times 9 \mathrm{~cm}$, firm in consistency and moves with deglutition. He was later diagnosed with multinodular goitre and total thyroidectomy was planned.

Prior to operation, he was referred to us for vocal cord assessment. On flexible nasopharyngolaryngoscopy (FNPLS), a large smooth-surfaced mass at the vallecula was obsereved (Figure 1). Another swelling also noted at left arytenoid region (Figure 2). Otherwise, laryngeal anatomy was unremarkable, and mobility of vocal cords was normal bilaterally. Computed tomography (CT) of the neck showed a well-defined hypodense cystic lesion of size approximately $2.5 \mathrm{~cm} \times 1.7 \mathrm{~cm}$ at vallecula region (Figure 3 ).

Cyst was operated under general anesthesia in the same session with total thyroidectomy. Intra-

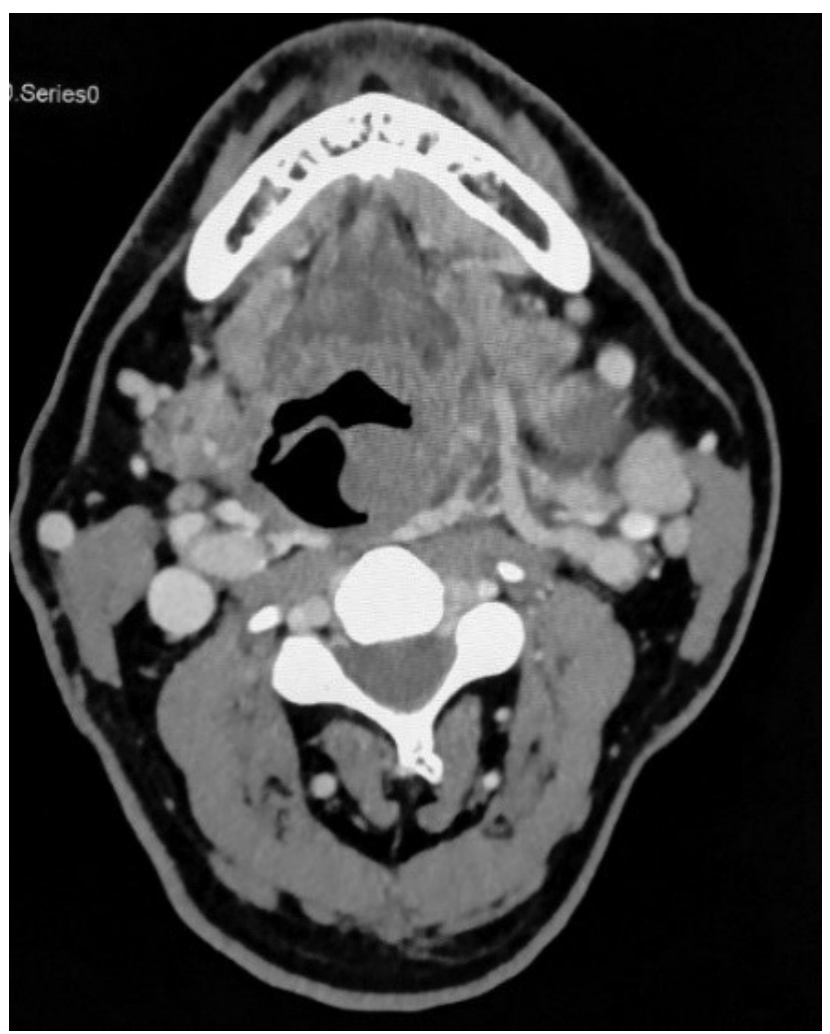

Figure 3. Axial CT neck showing the laryngeal cyst. 
operatively, three laryngeal cysts were found, one at the left vallecula measuring $4 \mathrm{~cm} \times 3 \mathrm{~cm}$, one at the right vellecula measuring $0.5 \mathrm{~cm} \times 0.5 \mathrm{~cm}$

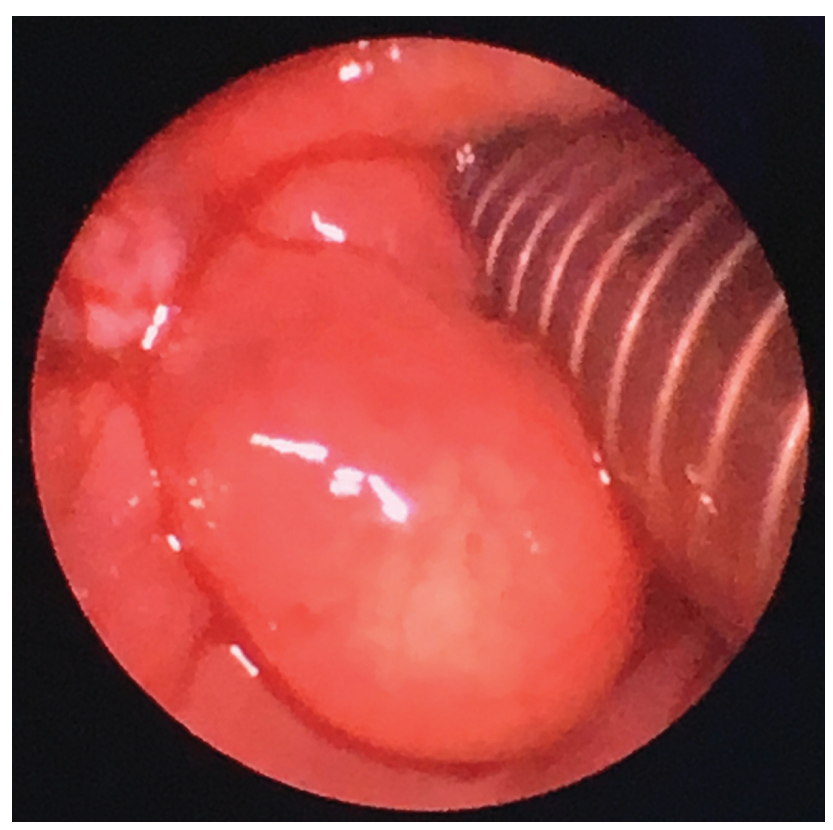

Figure 4. A large vallecula cyst before excision.

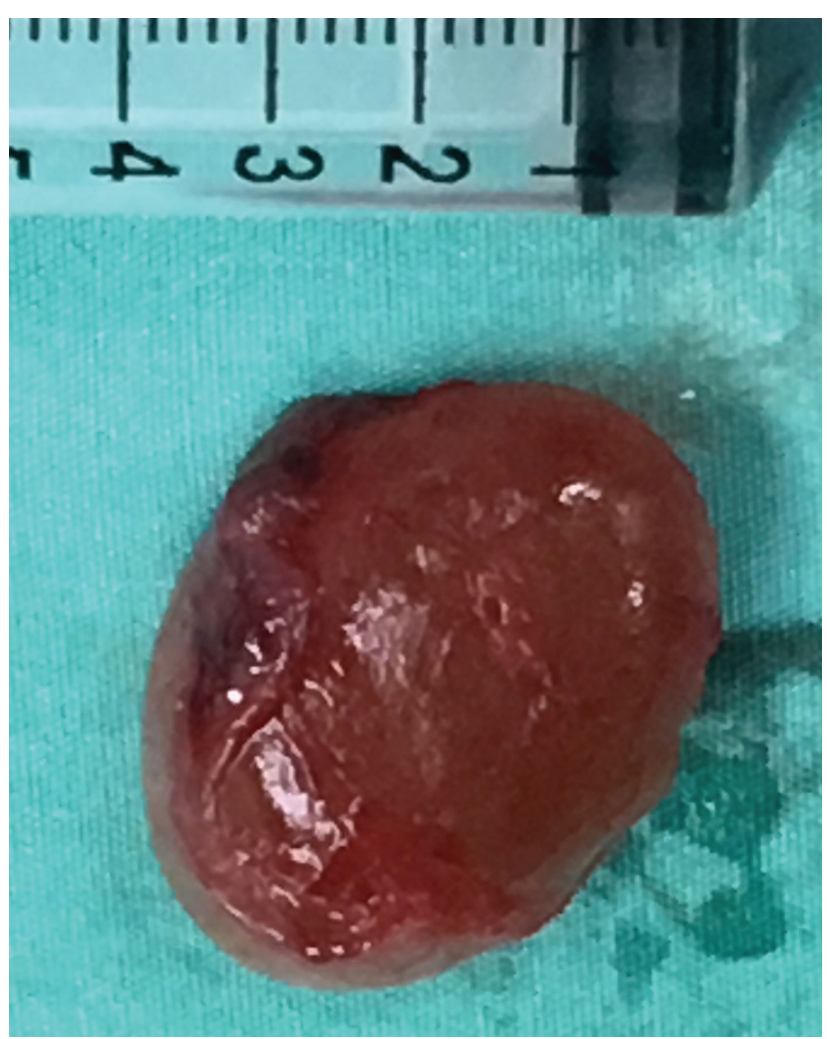

FIgure 5. A cyst from left vallecula was excised. and another one at left arytenoid measuring $2 \mathrm{~cm}$ $x 1 \mathrm{~cm}$ (Figure 4). All the three cysts were excised completely via endoscopic laryngealmicrosurgery (ELMS) (Figure 5).

As histopathologic examination (HPE) report confirmed, it was a simple cyst with no evidence of malignancy. On our regular follow up, about one month postoperatively, any evidence of residual cyst was not detected during our routine FNPLS procedure and patient was completely well.

\section{DISCUSSION}

Laryngeal cyst is an uncommon lesion, only constitutes $4.3 \%$ to $6 \%$ of all benign laryngeal lesions ${ }^{4}$. Incidence of laryngeal cysts is estimated to be low. There is a slight male predominance, and it is seen more frequently in the fifth and sixth decades $^{5}$. Laryngeal cysts are classified as ductal and saccular cysts ${ }^{6}$. Most common laryngeal cysts are ductal cysts, accounting for $75 \%$ of the cases. It is formed because of retention and obstruction of mucus in the collecting ducts of the submucosal glands. Saccular cysts arise from the saccule and extend to the ventricle ${ }^{6}$.

Lingual surface of the epiglottis and in the vallecular space are the commonest location of these cysts ${ }^{4}$. Laryngeal cysts become symptomatic depending on the size of the cyst, age of the patient, as well as extension into the airway. Approximately two-thirds of laryngeal cysts are asymptomatic and usually incidentally found upon laryngoscopy examination, like in our case or during induction of general anesthesia. However, an asymptomatic laryngeal cyst may cause respiratory or other complications if left untreated. Stridor, hoarseness, swelling in the throat, foreign body sensation and dysphagia are some reported symptoms ${ }^{2}$.

There were a few options of treatment in the management of laryngeal cysts. In the presence of sign and symptoms of respiratory distress or endotracheal intubation is not possible due to lary- 
ngeal obstruction, then immediate intervention may be required. The traditional method include excision, marsupialisation, snaring of the cyst using tonsillectomy set or direct vision of electrocautery method with or without microlaryngosco$\mathrm{pe}^{7}$. Recurrences are rare in total excisions. In our case surgery was achieved without local complication and any residual tumor was not observed at two month follow-up. Since patient was asymptomatic and the cyst was an incidental finding during our laryngoscopy examination, we believed that there was no association between his multinodular goitre and multiple laryngeal cyst. This was confirmed by HPE of the laryngeal cyst, which revealed a simple cyst with no evidence of malignancy or thyroid extension.

\section{CONCLUSION}

Laryngeal cysts are very rare, and generally asymptomatic in adults, like in our case but symptomatic in children. Most of the cases are found during routine laryngoscopy examination. Although rare, prompt detection and management of these relatively asymptomatic lesions will provide benefit to the patient by preventing future development of a life-threatening condition when endotracheal intubation is needed in the presence of an obstructive laryngeal cyst.

\section{REFERENCES}

1. Parelkar SV, Patel JL, Sanghvi BV, et al. An unusual presentation of vallecular cyst with near fatal respiratory distress and management using conventional laparoscopic instruments. J Surg Tech Case Rep. 20121;4:118-20. [CrossRef]

2. Romak JJ, Olsen SM, Koch CA, Ekbom DC. Bilateral vallecular cysts as a cause of Dysphagia: case report and literature review. Int J Otolaryngol. 2010;2010:697583. [CrossRef]

3. Hsieh W-S, Yang P-H, Wong K-S, Li H-Y, Wang E-R, Yeh T-F. Vallecular cyst: an uncommon cause of stridor in newborn infants. Eur J Pediatr. 2000;159:79-81. [CrossRef]

4. Yoon TM, Choi JO, Lim SC, Lee JK. The incidence of epiglottic cysts in a cohort of adults with acute epiglottitis. Clin Otolaryngol. 2010;35:18-24. [CrossRef]

5. Arens C, Glanz H, Kleinsasser O. Clinical and morphological aspects of laryngeal cysts. Eur Arch Otorhinolaryngol. 1997;254:430-6. [CrossRef]

6. Desanto LW, Devine KD, Weiland LH. Cysts of the larynx-classification. Laryngoscope. 1970;80:145-76. [CrossRef]

7. Singhal SK, Verma H, Dass A, Punia R. Vallecular cysts in adult population: ten year experience. Nepalese Journal of ENT Head \& Neck Surgery. 2014;3:5-7. [CrossRef] 